\title{
Economic feasibility of implementing an infrastructure for collecting rainwater from the roof of free-stall sheds
}

\section{Viabilidade econômica da implantação da infraestrutura para captação da água da chuva do telhado de galpões de free-stall}

Fabiana Alves Demeu'; Marcos Aurélio Lopes ${ }^{2 *}$; Julio Cesar Pascale Palhares ${ }^{3}$; André Luis Ribeiro de Lima4; Francisval de Melo Carvalho ${ }^{4}$; Marcos Aurélio Lopes Filho5; Andréia Alves Demeu; Douglas Alves Vidal7; Marina de Luca Lima ${ }^{8}$, Matteo Barbari ${ }^{9}$

\section{Highlights}

The feasibility of capturing rainwater from free-stall shed roof was analyzed.

MOP (most likely, optimistic, and pessimistic) scenarios were analyzed.

Rainwater capture was not economically viable.

Payback and cost-benefit ratio were unsatisfactory.

\begin{abstract}
This study aimed to analyze the economic feasibility of implementing and using the necessary infrastructure to collect rainwater from the roof of free-stall sheds in a dairy production system in southern Minas Gerais, Brazil. Specifically, the total cost (TC), total operating cost (TOC), and actual operating cost (AOC) of a cubic meter of rainwater and the break-even point in cubic meters were estimated. The research was conducted from January to December 2017 on a property located in the south of Minas Gerais. The following MOP scenarios were analyzed: most likely (Scenario 1), optimistic (scenario 2), and pessimistic (scenario 3). The grant value of the Das Velhas River basin was considered for the most likely scenario, as it has the most

1 PhD Student in the Veterinary Sciences Graduate Program, Federal Institute of Rondônia, IFRO, RO, Brazil. E-mail: fabiana.alves@ifro.edu.br

2 Ful Prof. at the Department of Veterinary Medicine, Federal University of Lavras, UFLA, Lavras, MG, Brazil. E-mail: malopes@ufla.br

3 Researcher at the EMBRAPA Livestock Southeast Research Center, EMBRAPA Pecuária Sudeste, São Carlos, SP, Brazil. E-mail: julio.palhares@embrapa.br

4 Profs., at the Department of Business and Economy, UFLA, Lavras, MG, Brazil. E-mail: andre.lima@ufla.br; francarv@ufla.br

${ }^{5} \mathrm{PhD}$ Student in the Global Health and Sustainability Graduate Program, University of São Paulo, USP, São Paulo, SP, Brazil. E-mail:marcos.lopes.fh@gmail.com

${ }^{6}$ Self-employed Zootechnician, Porto Velho, RO, Brazil. E-mail: demeuaa@gmail.com

7 Self-employed Agronomist, Lavras, MG, Brazil. E-mail: douglas95max@hotmail.com

8 Self-employed Veterinary Physician, Lavras, MG, Brazil. E-mail: mahlimamuz@hotmail.com

9 Prof. at University of Florence, Università Degli Studi Di Firenze, UNIFI, Italy. E-mail: matteo.barbari@unifi.it

* Author for correspondence
\end{abstract}

Received: July 30, 2020 - Approved: Oct. 03, 2020 
similar value with that of the basin surrounding the Furnas reservoir, in which the property is inserted. The grant value for water collection and consumption from the Paraíba River basin was considered in Scenario 2 , as this Federal basin has the lowest grant value. The grant value for water collection and consumption from the Piracicaba, Jundiaí, and Capivari river basins was considered in Scenario 3, as these basins have the highest prices for the cubic meter of the collected and consumed water. The implementation of the infrastructure for collecting rainwater from the roof of free-stall sheds under the studied conditions was economically unfeasible for all scenarios, with negative net present values (NPV). Simple and discounted paybacks were longer than the proposed horizon. The internal rate of return (IRR) could not be estimated due to the negative values of the net cash flow. The benefit-cost ratios (BCR) were unsatisfactory (lower than 1). The TC values for rainwater collection from the roof of free-stall sheds were $R \$ 23,206.59$ and $R \$$ $20,489.25$ for scenarios with interest rates of 8.50 and $6.99 \%$, respectively, while the TOC value was $R \$$ $7,850.30$ for all analyzed scenarios. The unit values for TOC and AOC were $R \$ 9.9024 / \mathrm{m}^{3}$ and $\mathrm{R} \$ 1.3060 / \mathrm{m}^{3}$ of collected water, respectively. The break-even point could not be estimated in the studied scenarios, as the variable cost per cubic meter of water collected from the roof of the free-stall shed was higher than the grant value charged by the water management committees of the different studied basins.

Key words: Scenario analysis. Dairy cattle farming. Profitability indicators. Reuse. Sustainability.

\section{Resumo}

Objetivou-se analisar a viabilidade econômica da implantação e utilização da infraestrutura necessária para a captação da água da chuva do telhado de galpões de free-stall, em um sistema de produção de leite no sul de Minas Gerais. Especificamente, pretendeu-se estimar o custo total (CT), custo operacional total (COT) e custo operacional efetivo (COE) de um metro cúbico da água captada da chuva, e estimar o ponto de equilíbrio da quantidade, em metros cúbicos. A pesquisa foi realizada em uma propriedade localizada no sul de Minas Gerais, no período entre janeiro a dezembro de 2017. Realizou-se a análise de cenários MOP: mais provável (cenário 1), otimista (cenário 2) e pessimista (cenário 3). Para o cenário mais provável, foi considerado o valor de outorga da bacia do Rio das Velhas, por ser aquela com cobrança de outorga mais próxima da bacia hidrográfica do entorno do reservatório de Furnas, na qual a propriedade está inserida. No cenário 2, consideraram-se as seguintes situações: preço de outorga para captação e consumo da água da bacia do Rio Paraíba, por ser a bacia federal de menor valor; e, no cenário 3, considerou-se a cobrança da outorga de captação e consumo da água da bacia dos rios Piracicaba, Jundiaí e Capivari, que praticam os maiores preços para o metro cúbico de água captada e consumida. A implantação da infraestrutura da captação da água da chuva do telhado de galpões de free-stall, nas condições estudadas, não apresentou viabilidade econômica em nenhum dos cenários estudados, apresentando valor presente líquido (VPL) negativo em todos os cenários. O payback simples e descontado ficaram acima do horizonte proposto. Não houve a possibilidade de estimar a TIR (taxa interna de retorno) devido aos valores negativos no fluxo líquido de caixa. As relações benefício/custo (RBC) não foram satisfatórias (menores que 1). Os CT da captação de água de chuva de telhado de free-stall foram de $\mathrm{R} \$ 23.206,59$ e de $\mathrm{R} \$ 20.489,25$, para os cenários com juros de 8,50 e 6,99\%, respectivamente, enquanto o COT foi de $\mathrm{R} \$ 7.850,30$, em todos os cenários analisados. Em relação aos valores unitários, foram de $\mathrm{R} \$ 9,9024 /$ $\mathrm{m}^{3}$ (COT) e de $\mathrm{R} \$ 1,3060 / \mathrm{m}^{3}$ (COE) de água captada. Não foi possível estimar o ponto de equilíbrio em nenhum cenário, pois o custo variável do metro cúbico da água captada do telhado do galpão de free-stall foi superior ao valor cobrado pela outorga de água pelos comitês de gestão de água das diferentes bacias estudadas.

Palavras-chave: Análise de cenários. Bovinocultura leiteira. Indicadores de rentabilidade. Reuso. sustentabilidade. 


\section{Introduction}

Sustainability in animal production has been the concern of several researchers and object of study in several studies, such as the use of the concept of design for deconstruction (DfD), which has the potential to limit the environmental impact of construction by supporting the disassembly and reuse of building materials at the end of life, reducing the use of concrete (Leso, Conti, Rossi, \& Barbari, 2018); raw earth (unburned clay bricks) as material for building facilities, replacing more expensive materials, but with lower thermal characteristics and higher environmental impact (Barbari, Monti, Rossi, Simonini \& Guerri, 2014a, 2014b); cereal straw packed in rectangular bales, as occurs directly after harvesting in the field, which is increasingly used in buildings as an element for filling walls, as it has high sustainability (Conti et al., 2017); and facilities designed taking into account the needs of outdoor animals and the choice of suitable building materials available in the region (Rossi, Conti, Bambi, Monti, \& Barbari, 2018). However, these studies have not evaluated the economic feasibility, which can direct cattle farmers to technologies that, in addition to reducing the environmental impact of the activity, and will contribute to reducing its production costs.

The United Nations Environment Programme (UNEP) has drawn Member States' attention for at least a decade to the enormous potential of rainwater collection and storage tools to ensure access to water for millions of people while promoting sustainable development (United Nations Environment Programme [UNEP], 2009). In 2015, within the framework of the 2030 Agenda for Sustainable Development, the 193 Member States of the
United Nations finally agreed on the centrality of water resources management to achieve the global purpose of guaranteeing social, economic, and environmental sustainability, recognizing in 2017 that the collection and storage of rainwater directly contribute to the fulfillment of Sustainable Development Goals 4 and 6 (Sustainable Development Goas Fund [SDGF], 2017).

Given the need to conserve an essential good such as water, which is under risk of scarcity, some alternatives for its conservation and efficient use have been proposed in recent decades. The possibility of reusing water or using wastewater and collecting rainwater are among them. Ministério do Meio Ambiente (2005) reported that these techniques reduce the demand for water catchment from sources. Gris, Bertolini and Johann (2017) stated that rainwater collection could occur in urban and rural areas.

Law 9,433 of January 8, 1997 (Lei $\mathrm{n}^{\circ}$ $9.433,1997)$, established the national policy of water resources, general guidelines for use, sharing, and charging for water use. Thus, Dorigon and Tessaro (2010) stated that charging for water use, even in rural areas, creates a demand for technicians and cattle farmers in search of alternatives to reduce its consumption, use it rationally, and prioritize sustainability.

Expectations of reinforcing the implementation of technologies such as the reuse and collection of rainwater in rural properties have gained higher visibility with the implementation of the national policy of water resources. According to Martins and Oliveira (2011), the replacement of supply sources is the best indication due to restrictions regarding the drinking water, which must be 
reserved for noble purposes, while rainwater and water reuse are destined for non-noble purposes. L. S. Santos (2015) stated that the main advantage of collecting rainwater is the reduction in the exploitation of available water resources and thereby the sustainability of the local activity. The highest cost that can be paid for water is the lack of it.

Studies on rainwater collection and its use in the agricultural environment can be a very important alternative for the preservation of water resources, preventing activities that need water in the rural environment from being compromised and, consequently, the supply of food to humans (Silva, Moreira, \& Peres, 2012). Considering the importance of this subject, several researchers have studied the collection of rainwater in homes (Machione \& Lopes, 2015; Zocolotti \& Haus, 2015) and the metalworking industry (Teixeira, Zattoni, Nagalli, Freira, \& Teixeira, 2016), and for animal production (Palhares, 2016). However, no research was found to analyze the economic feasibility of implementing the infrastructure for collecting rainwater from the roof of freestall sheds. Thus, this study aimed to analyze the economic feasibility of implementing an infrastructure to collect rainwater from the roof of the free-stall shed in a dairy production system in southern Minas Gerais. Specifically, the total cost (CT), total operating cost (TOC), and actual operating cost (AOC) of a cubic meter of rainwater and the break-even point in cubic meters were estimated.

\section{Material and Methods}

The research was carried out from January to December 2017 on a property located in the south of Minas Gerais. The intensive dairy production system was used, with the housing of all lactating and pre-calving cows in two free-stall sheds with dimensions of $90 \times 30 \mathrm{~m}$ (Shed 1) and $60 \times 30 \mathrm{~m}$ (Shed 2), with a capacity of approximately 428 Holstein cows. The average daily production reached $11,864.95 \mathrm{~kg}(+1,388.79 \mathrm{~kg})$, with an average of $32.28 \mathrm{~kg}(+2.68 \mathrm{~kg})$ of milk per lactating cow in three milkings. The complete diet, with corn (Zea mays) silage and concentrate was provided three times a day on a drive-through feed alley.

Two different stages were considered in the survey of information, according to the methodology used by Lopes et al. (2019) and Pelegrini et al. (2019). In the first stage, a form and field book were used to perform a complete inventory of the infrastructure and goods. Subsequently, the surveyed items were allocated to one of the following groups: improvements, machinery, and equipment.

Each improvement (gutters, PVC pipes, and cisterns for water storage) was measured and a summary of the descriptive memorial was registered. A value per square meter of construction was estimated as a function of the area, state of conservation, and finishing pattern. The current value was the product of the square meter value by the improvement area (Lopes et al., 2019). Also, a motor pump set used to conduct water to the reservoirs was considered in the machinery group.

In the second stage, the production system was visited and the files consulted for data collection regarding actual operating expenses, using field handbooks prepared for this purpose. The items that make up the actual operating cost of collecting rainwater were divided into the following groups: labor, fixed taxes, maintenance, and other expenses. 
A rate of $4 \%$ of the asset values was adopted for the item infrastructure maintenance (Haack \& Oliveira, 2013) and rates of 8.50 and $6.99 \%$ were adopted for the return on working capital, considering $20 \%$ of the AOC, as recommended by Lopes et al. (2016). These data were recorded in a spreadsheet developed specifically for the electronic processing of data and the analysis of the economic feasibility of rainwater collection technology. This spreadsheet included the two production cost structures, that is, total costs, related to the fixed and variable costs, and operating costs, both used by Lopes et al. (2019) and Pelegrini et al. (2019). The straightline depreciation method was used in this study (Moraes et al., 2018).

The Azevedo Neto method, proposed in ABNT NBR 15,527 (Associação Brasileira de Normas Técnicas [ABNT], 2007) was adopted to estimate the amount of water to be collected and dimension the reservoir. The average annual precipitation $(1,397.40 \mathrm{~mm})$ was estimated using the data from the historical series of Guimarães, Reis and Landau (2010) for llicínea, MG, over 20 years.

The values in the spreadsheet available on the website of the Minas Gerais Water Management Institute (IGAM) referring to the Das Velhas River tributary basin (Instituto Mineiro de Gestão de Águas [IGAM], 2017) were replace with the estimated amount of water collected per year.

The estimated annual water consumption was $7.36 \mathrm{~m}^{3}$ of water per cow per month, as recommended by L. S. Santos (2015). This value was multiplied by the average number of lactating cows and then by the number of months in one year (12).
Savings in $A O C$ reduction due to the purchase of water (in cubic meters) multiplied by the amount charged by the Sanitation Company of Minas Gerais (COPASA) for cleaning the facilities were considered as revenue in the cash flow. The indicators net present value (NPV), internal rate of return (IRR), and simple and discounted payback were estimated according to the methodology used by Lopes, Junqueira, Bruhn, Demeu and Silva (2017) and Lopes et al. (2018), while the benefit-cost ratio-1 (BCR) was estimated according to Haraguchi, Siddiqi and Narayanamurti (2019). A 10-year horizon was adopted in estimating these indicators. Two scenarios were simulated for the discount rate (DR): $8.50 \%$ per year, as it is the financing rate available to farmers who are willing to implement activities of this nature; and $6.99 \%$ per year, as it is the savings interest rate, accumulated in 2017 (Portal Brasil, 2017).

The most likely, optimistic, and pessimistic scenarios, that is, Scenarios 1, 2, and 3 , respectively, were used according to Lage et al. (2016). The price of $\mathrm{R} \$ 0.0152$ per cubic meter of water, charged by the Paraíba River Basin Committee, was considered in Scenario 1. The optimistic scenario (2) considered the values stipulated by the Piracicaba, Jundiaí, and Capivari River Basin Committee, which were $\mathrm{R} \$ 0.0130$ and $\mathrm{R} \$$ 0.0262 per cubic meter of collected and consumed water, respectively. On the other hand, the pessimistic scenario (3) considered the charge for use of water by the Das Velhas River Basin Committee, as it has the most similar value with that of the basin surrounding the Furnas reservoir, in which the property is inserted, with values of $\mathrm{R} \$ 0.01$ and $\mathrm{R} \$ 0.02$ per $\mathrm{m}^{3}$ of collected and consumed water, 
respectively, which were the lowest values considered in the simulations. The latter is multiplied by the correction factor of 0.025 , as it is the use of water for animal production (Câmara Técnica do CBHSF, 2017). All values referring to the cubic meter of water were quoted considering the values charged by COPASA in the llicínea region in July 2017.

The economic indices were compared through descriptive analyses, using the software MS Excel ${ }^{\circledR}$, and grouped in tables, aiming at a better comparison, discussion, and presentation of results (Lopes et al., 2019).

\section{Results and Discussion}

A summary of the resources needed to collect rainwater from the roof of freestall sheds in a dairy production system in the south of Minas Gerais is shown in Table 1. These resources were useful in analyzing and discussing the results found in this research. The highest values were spent on improvements, which corresponded to $68.15 \%$ of investments. The area destined to the cistern implementation, despite having a lower percentage (18.20\%) compared to the group improvements, should be considered because it could be for another productive activity. Comparisons regarding values and percentages for the implementation of the infrastructure to collect rainwater were not possible because of the lack of details of investments in the few studies found in the literature (M. Santos, Carvalho, Ramos, Dias, \& Reis, 2016; Teixeira et al., 2016). Also, some of these studies lack information such as investment in catchment gutters and/or the area where the cistern is located (Teixeira et al., 2016). Moreover, the evaluations were conducted for other economic activities, such as soft drink (M. Santos et al., 2016) and metalworking industries (Teixeira et al., 2016), and homes (Machione \& Lopes, 2015; Zocolotti \& Haus, 2015). Another point that makes comparison difficult is that the researchers did not consider the land value, which may be underestimating the investment and may lead to a misunderstanding in the expansion advice because although the area looks small, its value is high, especially when the investment is in the urban perimeter, where land is more valued.

The fixed asset per housed cow of $\mathrm{R} \$$ $419.97(0.23 \%$ of the infrastructure to collect rainwater) represented only $2.05 \%$ of the $R \$$ $20,466.11$ (US $\$ 6,277.95$ ) fixed per housed cow of the production system, but not considering the land.

The estimated rainwater collection was 475,659.59 liters year-1, which represented $1.50 \%$ of the $31,795,200.00$ liters planned to clean the milking parlor. 
Table 1

Available resources for the implementation of the infrastructure to collect rainwater from the roof of free-stall sheds in a dairy production system in the south of Minas Gerais in 2017 (R\$ and US\$)

\begin{tabular}{|lccc}
\hline \multicolumn{1}{c}{ Specification } & Value (R\$) & Value (US\$) & (\%) \\
\hline Equity value with land & $40,000.00$ & $12,539.18$ & 18.20 \\
Equity value without land & $179,749.20$ & $56,347.71$ & 81.80 \\
Value of improvements & $149,749.20$ & $46,943.32$ & 68.15 \\
Value of machines & $30,000.00$ & $9,404.39$ & 13.65 \\
Value of equipment & 0.00 & 0.00 & 0.00 \\
\hline Total fixed assets & $219,749.20$ & $68,886.90$ & 100.00 \\
Fixed assets per housed cow & 419.97 & 129.43 & 0.23
\end{tabular}

US\$ 1.00 equal to R\$3.26, average price from 01/01 to 12/31/2017 (Banco Central do Brasil[BBC], 2018).

The investment in infrastructure for collecting rainwater from the roof of free-stall sheds was not promising economically under all studied scenarios because it presented negative NPV values of $R \$-231,907.22, R \$$ $-231,718.01$, and $R \$-231,292.72$ for Scenarios 1,2 , and 3, respectively, considering a DR of $8.50 \%$, and $\mathrm{R} \$-232,113.64, \mathrm{R} \$-231,924.11$, and $\mathrm{R} \$-232,150.76$ for Scenarios 1, 2, and 3, respectively, when considering a DR of $6.99 \%$. Simple and discounted paybacks were higher than the proposed horizon. IRR could not be estimated due to the negative values in the net cash flow. The benefit-cost ratio-1 (BCR) was not satisfactory (lower than 1), ranging from -0.04 to -0.05 , indicating that the project costs are higher than the benefits it can provide. In this case, the investment required is higher than the financial return (Chenço, 2016). These results show, in practical terms, the destruction of assets, and the producer must analyze other investment alternatives if the main objective is the financial return. However, it is worth mentioning the importance of preserving water resources. Thus, a cistern is an alternative if there is a need to preserve water sources of the property in its volume, considering scenarios of water scarcity and/or seasonal climate conditions.
Agricultural production systems need investments to mitigate environmental impacts, but productive activity can be rendered unfeasible if they are not conciliated with the reduction in costs. Thus, there is a need to know the production system and its costs, thus allowing the use of all the productive potential, maximizing profits, and identifying bottlenecks to correct them and ensure economic and environmental sustainability once the environmental impacts caused by the developed activities is reduced.

No economic feasibility studies regarding the collection of rainwater from the roofs of free-stall sheds have been found in the scientific literature. Studies on rainwater collection under other situations (rainwater catchment in homes, schools, and industrial sector) have also not shown promising results, as observed by Zocolotti and Haus (2015), who studied rainwater collection in the popular single-family housing model of the Brazilian Federal Savings Bank. In the present study, investment in cisterns represented $60.10 \%$ of the total investment in improvements and $40.96 \%$ of the total investments and may have contributed, in large part, to the system's 
lack of economic feasibility. Machione and Lopes (2015) studied the economic and environmental feasibility of collecting rainwater in $100-\mathrm{m}^{2}$ residential buildings and obtained intermediate results due to the long return of the invested amounts, but the environmental feasibility stands out over the others.

Teixeira et al. (2016) studied two alternatives for collecting rainwater in a metalworking industry in the metropolitan region of Curitiba, $\mathrm{PR}$, and only the alternative with storage in geomembrane showed economic feasibility. However, the survey did not consider the costs of pumping, piping, and pollutant emissions, which could be underestimating the values.

Table 2 shows a summary of the profitability analysis of rainwater collection from the roof of free-stall sheds under the proposed scenarios. The expectation of total annual revenue was $R \$ 12.05, R \$ 31.08$, and $\mathrm{R} \$ 8.32$ for Scenarios 1, 2, and 3, respectively. These small values are justified by the insignificant values paid for water collection and consumption in Brazil. They correspond to the sum of the values calculated with the collection savings, which were $100,33.26$, and $95.31 \%$ for Scenarios 1, 2, and 3, respectively. Savings on consumption expenses regarding the collected water were estimated at 66.74 and $4.69 \%$ for Scenarios 2 and 3, respectively; Scenario 1 has no specific value established by the basin Committee for consumed water, only for the collected water. Revenue in Scenarios 2 and 3 was composed by the value of the savings with the reduction in water collection and consumption, as these items allow the charges made by the considered Basin Committees. The charge in scenario 1 occurs only for water collection, which results in a zero value for water consumption (Table 2).
The total cost of the cubic meter of water of $\mathrm{R} \$ 29.27$ and $\mathrm{R} \$ 25.85$ for scenarios with discount rates of 8.50 and $6.99 \%$, respectively, are well above the values established for the charge rates by water use practiced by all Basin Committees and by the National Water Agency. Currently, the highest values $(\mathrm{R} \$ 0.0130$ per collected $\mathrm{m}^{3}$ and $\mathrm{R} \$ 0.026$ per consumed $\mathrm{m}^{3}$ ) are practiced in the Piracicaba, Jundiaí, and Capivari River basins. Apparently, the amounts charged for water collection and consumption in Brazil is only to have control over who consumes and know the purpose of consumption (human and animal consumption or irrigation).

L. S. Santos (2015) carried out research in Inconfidentes, MG, with dairy cattle, and considered only the values of materials and labor necessary for the implementation of a water collection system. This author estimated value of $\mathrm{R} \$ 45.46$ per $\mathrm{m}^{3}$ of collected water, which corresponded to a percentage lower than $55.17 \%$ of the lowest cost observed in this study $\left(\mathrm{R} \$ 25.85\right.$ per $\left.\mathrm{m}^{3}\right)$ considering an interest rate of $6.99 \%$. As in this study, the cost of one cubic meter of water was much higher than that charged by the water supply company (COPASA), which reached $\mathrm{R} \$ 4.72$ per $^{3}$ in the study of L. S. Santos (2015). No comparative value was verified for this study because the entire water supply of the property is made by an artesian aquifer, with no option for supply by a water company. However, the amount charged by COPASA in the commercial user category in the region of Ilicínea, MG, as of July 2017, was $\mathrm{R} \$ 10.303$ per $\mathrm{m}^{3}$ (referring to the water supply) (Companhia de Saneamento de Minas Gerais [COPASA], 2017), which is lower than TC in all studied scenarios. Thus, in this specific study, obtaining water from COPASA, if possible, would be more interesting than carrying out bank financing at this interest rate $(8.50 \%)$ to implement the infrastructure to collect rainwater from the roof of the free-stall shed. 


\section{Table 2}

Summary of the profitability analysis for the implementation of the infrastructure to collect rainwater from the roof of free-stall shed in a dairy production system in the south of Minas Gerais in 2017 (in R\$), considering two discount rates (DR) and different scenarios

\begin{tabular}{|c|c|c|c|c|c|c|}
\hline \multirow[b]{2}{*}{ Specification } & \multicolumn{2}{|c|}{ Scenario 1: most likely } & \multicolumn{2}{|c|}{ Scenario 2: optimistic } & \multicolumn{2}{|c|}{ Scenario 3: pessimistic } \\
\hline & $\begin{array}{l}\text { DR of } \\
8.50 \%\end{array}$ & $\begin{array}{l}\text { DR of } \\
6.99 \%\end{array}$ & $\begin{array}{l}\text { DR of } \\
8.50 \%\end{array}$ & $\begin{array}{l}\text { DR of } \\
6.99 \%\end{array}$ & $\begin{array}{l}\text { DR of } \\
8.50 \%\end{array}$ & $\begin{array}{l}\text { DR of } \\
6.99 \%\end{array}$ \\
\hline Revenue & 12.05 & 12.05 & 31.08 & 31.08 & 8.32 & 8.32 \\
\hline Savings with water abstraction & 12.05 & 12.05 & 10.31 & 10.31 & 7.93 & 7.93 \\
\hline Savings with water consumption & 0.00 & 0.00 & 20.77 & 20.77 & 0.40 & 0.40 \\
\hline Total operating cost & $7,850.30$ & $7,850.30$ & $7,850.30$ & $7,850.30$ & $7,850.30$ & $7,850.30$ \\
\hline Actual operating cost & $1,035.38$ & $1,035.38$ & $1,035.38$ & $1,035.38$ & $1,035.38$ & $1,035.38$ \\
\hline Depreciation cost & $6,814.92$ & $6,814.92$ & $6,814.92$ & $6,814.92$ & $6,814.92$ & $6,814.92$ \\
\hline Total cost & $23,206.59$ & $20,489.25$ & $23,206.59$ & $20,489.25$ & $23,206.59$ & $20,489.25$ \\
\hline Fixed costs & $22,153.60$ & $19,439.39$ & $22,153.60$ & $19,439.39$ & $22,153.60$ & $19,439.39$ \\
\hline Depreciation costs & $6,814.92$ & $6,814.92$ & $6,814.92$ & $6,814.92$ & $6,814.92$ & $6.814,92$ \\
\hline Land remuneration & 60.00 & 60.00 & 60.00 & 60.00 & 60.00 & 60.00 \\
\hline Return on invested capital & $15,278.68$ & $12,564.47$ & $15,278.68$ & $12,564.47$ & $15,278.68$ & $12,564.47$ \\
\hline Compensation of the entrepreneur & 0.00 & 0.00 & 0.00 & 0.00 & 0.00 & 0.00 \\
\hline Variable costs & $1,052.99$ & $1,049.86$ & $1,052.99$ & $1,049.86$ & $1,052.99$ & $1,049.86$ \\
\hline Actual operating cost & $1,035.38$ & $1,035.38$ & $1,035.38$ & $1,035.38$ & $1,035.38$ & $1,035.38$ \\
\hline Return on working capital & 17.60 & 14.47 & 17.60 & 14.47 & 17.60 & 14.47 \\
\hline Gross margin & $-1,023.33$ & $-1,023.33$ & $-1,004.31$ & $-1,004.31$ & $-1,027.06$ & $-1,027.06$ \\
\hline Net margin & $-7,838.25$ & $-7,838.25$ & $-7,819.23$ & $-7,819.23$ & $-7,841.98$ & $-7,841.98$ \\
\hline Result (profit or loss) & $-23,194.54$ & $-20,477.20$ & $-23,175.51$ & $-20,458.17$ & $-23,198.26$ & $-20,480.92$ \\
\hline $\begin{array}{l}\text { Actual operating cost per } \mathrm{m}^{3} \text { of } \\
\text { collected water }\end{array}$ & 1.3060 & 1.3060 & 1.3060 & 1.3060 & 1.3060 & 1.3060 \\
\hline Total operating cost per $\mathrm{m}^{3}$ & 9.9024 & 9.9024 & 9.9024 & 9.9024 & 9.9024 & 9.9024 \\
\hline Variable cost per $\mathrm{m}^{3}$ & 1.3282 & 1.3243 & 1.3282 & 1,3243 & 1.3282 & 1.3243 \\
\hline Fixed cost per $\mathrm{m}^{3}$ & 27.9447 & 24.5210 & 27.9447 & 24,5210 & 27.9447 & 24.5210 \\
\hline Total cost per $\mathrm{m}^{3}$ & 29.2729 & 25.8453 & 29.2729 & 25,8453 & 29.2729 & 25.8453 \\
\hline $\begin{array}{l}\text { Price per } \mathrm{m}^{3} \text { (collected }+ \\
\text { consumed) }\end{array}$ & 0.0152 & 0.0152 & 0.0392 & 0,0392 & 0.0105 & 0.0105 \\
\hline Price per $\mathrm{m}^{3}$ of the collected water & 0.0152 & 0.0152 & 0.0130 & 0,0130 & 0.0100 & 0.0100 \\
\hline $\begin{array}{l}\text { Price per } \mathrm{m}^{3} \text { of the consumed } \\
\text { water }\end{array}$ & - & - & 0.0262 & 0,0262 & 0.0050 & 0.0050 \\
\hline $\begin{array}{l}\text { Break-even point ( } m^{3} \text { of water per } \\
\text { year) }\end{array}$ & ** & $* *$ & ** & ** & ** & ** \\
\hline Amount of $\mathrm{m}^{3}$ of collected water & 475.66 & 475.66 & 475.66 & 475,66 & 475.66 & 475.66 \\
\hline
\end{tabular}

US\$ 1.00 equal to $R \$ 3.19$, average price from $01 / 01$ to $12 / 31 / 2017$ (BBC, 2018). Values of inputs and products were obtained at the local market in the south of Minas Gerais (Reference period: February 2018). ${ }^{* *}$ Not possible to estimate, as the market value is lower than the variable unit cost. 
However, future projections for water demand should raise the values of abstraction and consumption, as the law of supply and demand regulates the market and alternatives of this magnitude may become viable in the not too distant future with the lack of water in the world, mainly when the amount charged or to be charged for water becomes representative in the cost of milk production. This fact will lead technicians and cattle farmers to rethink agricultural practices and procedures for saving water. In this sense, Palhares, Afonso and Gameiro et al. (2018) proposed and evaluated a method to calculate the cost of water in livestock production considering the best practices in terms of residue management. They found that diets with more advanced nutritional technologies and better residue management had the lowest total water cost, regardless of the farm size.

The break-even point could not be estimated since the market value $(R \$ 0.015)$ is below the unit variable cost ( $R \$ 1.3243$ ) (Table 2) of the cubic meter of water. Thus, the clearing price was estimated and reached $\mathrm{R} \$ 29.87$ and $\mathrm{R} \$ 25.85$ per $\mathrm{m}^{3}$ of water for the discount rates of 8.50 and $6.99 \%$, respectively. In other words, there will only be economic feasibility in the implementation of this technology if the amount charged for collection and consumption is higher than $\mathrm{R} \$ 25.85$ per $\mathrm{m}^{3}$ of water, considering the lowest adopted interest rate.

Changes in the clearing price depend on the amount of collected rainwater, which depends on the precipitation, that is, it does not depend on the cattle farmer, except regarding the efficiency of collection. However, the clearing price is also a function of the total cost, which is the sum of the fixed and variable cost, which can be minimized by the cattle farmer by optimizing the use of some inputs (Lopes, Demeu, Barbosa, Brondino and Carvalho, 2015), which would not be applicable in the present study because there is no input acquisition. However, the value of input acquisition would not be significant under the studied conditions, as the variable costs represented only $1.95 \%$ of $\mathrm{TC}$, that is, the fixed costs were much more representative (98.05\%). The variable costs refer to expenses with repair and maintenance of improvements and machinery. Thus, efforts should be focused on their reduction, seeking to reduce the values invested in the infrastructure to collect rainwater through good market research (budgeting) (Lopes et al., 2018) and the search for alternative materials, which would require scientific research, thus contributing to reducing the fixed cost and, consequently, the clearing price. Sources of financing with low-interest rates and long periods of grace and payments could also be options to encourage cattle farmers to adopt environmentally friendly technologies that minimize the impacts of dairy farming.

Despite the studied scenarios have not shown economic feasibility, rainwater collection is one of the measures that conserve the natural water sources that the dairy activity is dependent on and deserves attention for new studies that may propose alternatives to reduce its costs, including rainwater storage, thus becoming an economically feasible alternative.

Moreover, agricultural production systems need investments to mitigate environmental impacts and, when these alternatives promote reductions in costs, they can be promising to guarantee their economic and environmental sustainability. 
Economic feasibility studies with alternatives that minimize the environmental impact on dairy farming and rainwater collection must be carried out. The recovery of free-stall sand and the implementation of alternative sources of electricity generation (biogas, photovoltaic, and wind) are among these alternatives.

\section{Conclusions}

The implementation of the infrastructure for collecting rainwater from the roof of free-stall sheds under the studied conditions showed no economic feasibility for the studied scenarios (most likely 1, optimitic 2 , and pessimistic 3 ), with negative net present values. Simple and discounted paybacks were longer than the proposed horizon. The internal rate of return could not be estimated due to the negative values in the net cash flow. The benefit-cost ratio was not satisfactory (lower than 1).

The total costs of rainwater collection from the roof of free-stall sheds reached $\mathrm{R} \$$ $23,206.59$ and $R \$ 20,489.25$ for scenarios with interest rates of 8.50 and $6.99 \%$, respectively. The total operating cost reached $\mathrm{R} \$ 7,850.30$ in all analyzed scenarios. The unit values of the total and actual operating costs were $\mathrm{R} \$$ 9.9024 and $R \$ 1.3060$ per $\mathrm{m} 3$ of the collected water, respectively.

The break-even point could not be estimated in the studied scenarios because the variable cost $(\mathrm{R} \$ 0.5585$ per $\mathrm{m} 3)$ of the cubic meter of water collected from the roof of the free-stall shed was higher than the amount charged for the water grant by the management committees from the different studied basins.

\section{Acknowledgments}

The authors would like to thank the Instituto Federal de Ciência e Tecnologia de Rondônia (IFRO) for the financial support in translating this paper, CAPES for granting of a scholarship to the first author, and Fazenda Catete, on behalf of Mr Gustavo Portugal, for making available the property data for the study.

\section{References}

Associação Brasileira de Normas Técnicas (2007). NBR 15527: aproveitamento de água de chuva de coberturas em áreas urbanas para fins não potáveis. Rio de Janeiro: ABNT.

Banco Central do Brasil (2018). Dólar americano. Recuperado de http://www4. bcb.gov.br/pec/taxas/port/ ptaxnpesq. asp?id=txcotacao

Barbari, M., Monti, M., Rossi, G., Simonini, S., \& Guerri, F. S. (2014a). Proposal for a simple method of structural calculation for ordinary earthen buildings in rural areas. Journal of Food, Agriculture \& Environment, 12(2), 897-903. Retrieved from https://www.researchgate.net/ publication/275291723_Proposal_ for_a_simple_method_of_structural_ calculation_for_ordinary_earthen_ buildings_in_rural_areas

Barbari, M., Monti, M., Rossi, G., Simonini, S., \& Guerri, F. S. (2014b). Simple methods and tools to determine the mechanical strength of adobe in rural areas. Journal of Food, Agriculture \& Environment, 12(2), 904-909. Recuperado de https://www.researchgate. net/publication/275292515_Simple_ 
methods_and_tools_to_determine_the mechanical_strength_of_adobe_in_rural_ areas

Câmara Técnica do CBHSF (2017). Câmara TécnicadoCBHSFaprovanovametodologia de cobrança para o uso da água. Recuperado de http://cbhsaofrancisco. org.br/2017/ctoc-aprova-metodologia-decobranca-para-irrigacao-e-reajuste-deppu-em-20-para-todos-setores-usuarios/

Chenço, E. C. (2016). Fundamentos em finanças. Curitiba: IESDE Brasil AS.

Conti, L., Goli, G., Monti, M., Pellegrini, P., Rossi, G., \& Barbari, M. (2017). Simplified method for the characterization of Rectangular Straw Bales (RSB) thermal conductivity. Proceeding of the IOP Conference Series: Materials Science and Engineering, Prague, Czech Republic, Czech Republic, 245.

Companhia de Saneamento de Minas Gerais (2017). Tabela de tarifa: vigência a partir de 30/07/2017. Belo Horizonte: COPASA. Recuperadodehttp://www.copasa.com.br/ wps/wcm/connect/2ceffeba-7dd1-4d109b96-370373ef78e2/Tb_de_tarifa-2017. $\mathrm{df} ? \mathrm{MOD}=\mathrm{AJPERES} \& \mathrm{CACHEID}=2$ ceffeba7dd1-4d10-9b 96-370373ef78e2

Dorigon, E. B., \& Tessaro, P. (2010). Caracterização dos efluentes da lavação automotiva em postos de atividade exclusiva na região AMAI - Oeste catarinense. Unoesc \& Ciência - ACBS, 1(1), 13-22.

Gris, V. G. C., Bertolini, G. R. F., \& Johann, J. A. (2017). Cisternas rurais: viabilidade econômica e percepção de agricultores do município de Palotina-PR. Revista Nera, 37, 169-194. doi: 10.47946/ rnera. v0i37.4755
Guimarães, D.P., Reis, R. J., \&Landau, E. C. (2010). Índices pluviométricos em Minas Gerais. (Boletim de Pesquisa e Desenvolvimento, 30). Belo Horizonte: EMBRAPA.

Haack, S. C., \& Oliveira, G. G. de. (2013). Análise de viabilidade econômica e financeira de projetos sustentáveis no setor energético: estudo de caso para implantação de biodigestores no semiárido baiano. Revista Econômica do Nordeste, 44(Supl.), 363-382. Recuperado de https://ren. emnuvens.com.br/ren/ article/view/36/18

Haraguchi, M., Siddiqi, A., \& Narayanamurti, V. (2019). Stochastic cost-benefit analysis of urban waste-to-energy systems. Journal of Cleaner Production, 224(3), 751-765. doi: 10.1016/j.jclepro.2019.03.099

Instituto Mineiro de Gestão de Águas (2017). Simulação de valores de outorga de consumo e captação de água. Belo Horizonte: IGAM. Recuperado de http:// www.ief.mg.gov.br/

Lage, L. A., Lopes, M. A., Lopes, F. C. F., Gama, M. A. S., Ribeiro, C. G. S., Rogríguez, N. M., \& Demeu, F. A. (2016). Economic feasibility of adding sunflower oil to elephant grass-based diets of lactating dairy cows. Semina: Ciências Agrárias, 37(4, Supl. 1), 2313-2320. doi: 10.5433/16790359.2016v37n4 Supl1 p2313

Lei $n^{\circ}$ 9.433, de 8 janeiro de 1997. Institui a Política Nacional de Recursos Hídricos, cria o Sistema Nacional de Gerenciamento de Recursos Hídricos, regulamenta o inciso XIX do art. 21 da Constituição Federal, e altera o art. $1^{\circ}$ da Lei $n^{\circ} 8.001$, de 13 de março de 1990, que modificou a Lei n 7.990, de 28 de dezembro de 1989. Brasília, DF. Recuperado de http://www. planalto.gov.br/ccivil_03/Leis//9433.htm 
Leso, L., Conti, L., Rossi, G., \& Barbari, M. (2018). Criteria of design for deconstruction applied to dairy cows housing: a case study in Italy. Agronomy Research, 16, 794-805. doi: 10.15159/AR.18.085

Lopes, M. A., Demeu, A. A., Barbosa, F. A., Brondino, J., \& Carvalho, F. de M. (2015). Resultados econômicos da recria e engorda de novilhas de corte: um estudo de caso no município de Curvelo - MG, nos anos de 2008 e 2009. Archivos Latinoamericanos de Producción Animal, 23(2), 81-90. Recuperado de https://pdfs. semanticscholar.org/0b35/6264f5fd8ab9 f09eaffd5ec7b635141baec.pdf

Lopes, M. A., Junqueira, L. V., Bruhn, F. R. P., Demeu, A. A., \& Silva, M. das D. (2017). Technical efficiency and economic viability of different cattle identification methods allowed by the Brazilian traceability system. Semina: Ciências Agrárias, 38(1), 467480. doi: 10.5433/1679-0359.2017v38n1 p467

Lopes, M. A., Moraes, F. de, Bruhn, F. R. P., Carvalho, F. de M., Lima, A. L. R., Reis, B. E. M., \& Viafara, J. A. S. (2019). Análisis de la rentabilidad de la actividad lechera de propriedades participantes del programa "Balde Cheio". Revista de Medicina Veterinaria, 38(1), 15-27. doi: 10.19052/ mv.vol1.iss38.2

Lopes, M. A., Reis, E. M. B., Demeu, F. A., Mesquita, A. A., Rocha, A. G. F., Pelegrini, D. F.,... Teixeira, F. E. P., Jr. (2016). Uso de ferramentas de gestão na atividade leiteira: um estudo de caso no sul de Minas Gerais. Revista Científica de Produção Animal, 18(1), 26-44. doi: 10.25066/ agrotec.v39i1.34302
Lopes, M. A., Vieira, J. A., Lima, F. H. S. de, Demeu, F. A., Bruhn, F. R. P., Pereira, A.,... Casas, P. S. (2018). Technical and economic efficiency of bovine weighing methods. Semina: Ciências Agrárias, 39(3), 1167-1180. doi: 10.5433/1679-0359.2018v39n3p1167

Machione, E. D. C., \& Lopes, M. A. (2015). Análise da viabilidade econômico-ambiental da implantação de construções de $100 \mathrm{~m} 2$ de cobertura no município de ColinaSP. Unimontes Científica, 17(1), 1-15. Recuperado de https://www.periodicos. unimontes.br/index.php/unicientifica/ article/view/1929

Martins, F. M., \& Oliveira, P. A. V. de. (2011). Análise econômica da geração de energia elétrica a partir do biogás na suinocultura. Engenharia Agrícola, 31(3), 477-486. doi: 10.1590/S0100-69162011000300008

Ministério do Meio Ambiente (2005). Resolução $n^{\circ} 54$, de 28 de novembro de 2005. Estabelece modalidades, diretrizes e critérios gerais para a prática de reúso direto não potável de água. Brasília, DF. Recuperado de https://www.diariodasleis. com.br/busca/exibelink.php?numli $n k=1-173-34-2005-11-28-54$

Moraes, F., Lopes, M. A., Carvalho, F. M., Peres, A. A. C., Bruhn, F. R. P., Lima, A. L. R., \& Cardoso, M. G. (2018). Effect of the scale of production on the cost-effectiveness of milk production systems belonging to the "Balde Cheio" program. Semina: Ciências Agrárias, 39(3), 1211-1224. doi: 10.5433/ 1679- 0359.2018v39n3p1211

Palhares, J. C. P. (Org.) (2016). Produção animal e recursos hídricos. São Carlos: Cubo.

Palhares, J. C. P., Afonso, E. R., \& Gameiro, A. H. (2018). Reducing the water cost 
in livestock with adoption of best practices. Environment, Development and Sustainability, 1(4), 1-11. doi: 10.1007/s10 668-018-01 17-z

Pelegrini, D. P., Lopes, M. A., Demeu, F. A., Rocha, A. G. F., Bruhn, F. R. P., \& Casas, O. S. (2019). Effect of socioeconomic factors on the yields of family-operated milk production systems. Semina: Ciências Agrárias, 40(3), 1199-1214. doi: 10.5433/1679-0359.2019v40n3p1199

Portal Brasil (2017). Caderneta de poupança: índices mensais: rendimentos creditados no dia $1^{\circ}$ de cada mês. Brasília, DF. Recuperado de http://www.portalbrasil. net/poupanca_mensal.htm

Rossi, G., Conti, L., Bambi, G., Monti, M., \& Barbari, M. (2018). Poultry farming solutions for a sustainable development of marshlands areas of South Iraq. Agronomy Research, 16(2), 574-581. doi: 10.15159/ AR.18.058

Santos, L.S.(2015).Potencialdeaproveitamento da água de chuva na produção de leite: um estudo de caso. Dissertação de mestrado em Engenharia Agrícola, Universidade Estadual de Campinas, Campinas, SP, Brasil.

Santos, M., Carvalho, C. L. S., Ramos, J. C., Dias, F. C., \& Reis, M. F. (2016). Análise da viabilidade econômica de um sistema de captação de água da chuva: estudo de cada de uma indústria de refrigerantes. Revista Produção Industrial \& Serviços, 3(1), 50-63. Recuperado de https:// www. tratamentodeagua. com.br/artigo/ viabilidade-economica-captacao-deagua-da-chuva/
Silva, T. P. P. da, Moreira, J. C., \& Peres, F. (2012). Serão os carrapaticidas agrotóxicos?: implicações na saúde e na percepção de riscos de trabalhadores da pecuária leiteira. Ciência \& Saúde Coletiva, 17(2), 311-325. doi: 10.1590/S141381232012000200006

Sustainable Development Goas Fund (2017). Harvesting rainwater in rural Bolivia. Retrieved from https:// www.sdgfund.org/ harvesting-rainwater-rural-bolivia

Teixeira, C. A., Zattoni, G. T., Nagalli, A., Freira, F. B., \& Teixeira, S. H. C. (2016). Análise de viabilidade técnica e econômica do uso de água de chuva em uma indústria metalmecânica na região metropolitana de Curitiba PR. Gestão \& Produção, 23(30), 638-648. doi: 10.1590/0104-530x1655-14

United Nations Environment Programme (2009). Rainwater harvesting: a lifeline for human well-being. A report prepared for UNEP by Stockholm Environment Institute.

Zocolotti, F. M., \& Haus, T. L. (2015). Análise de análise de viabilidade ambiental e econômica para um sistema de captação de água da chuva no modelo habitacional unifamiliar popular da Caixa Economica Federal. Memorial TCC Caderno de Graduação, Curitiba, PR, Brasil. Recuperado de https:// memorial tcccadernograduacao.fae.edu/ cadernotcc/article/view/26 